\title{
Skills and Knowledge Competency of Technical and Vocational Education and Training Graduate
}

\author{
Ridzwan, C. R. ${ }^{1}$, S. Malik ${ }^{2}$, Zaliza Hanapi ${ }^{1}$, Suriani Mohamed ${ }^{1}$, Mohd Azlan Hussain ${ }^{1} \&$ Shafeeqa Shahrudin $^{1}$ \\ ${ }^{1}$ Faculty of Technical and Vocational Education, Universiti Pendidikan Sultan Idris, Malaysia \\ ${ }^{2}$ Faculty of Science and Mathematics, Universiti Pendidikan Sultan Idris, Malaysia \\ Correspondence: Ridzwan, C. R, Faculty of Technical and Vocational Education, Universiti Pendidikan Sultan \\ Idris, Malaysia. E-mail: ridzwan@fptv.upsi.edu.my
}

Received: January 8, 2017

doi:10.5539/ass.v13n4p69
Accepted: January 23, $2017 \quad$ Online Published: March 24, 2017

URL: https://doi.org/10.5539/ass.v13n4p69

\begin{abstract}
The Education Development Plan of Malaysia (Higher Education) carry the nation's aspiration to empower the technical and vocational education and training (TVET) in Malaysia. The emphasis on the development of high quality TVET graduates demands teachers and instructors of TVET who are highly knowledgeable and skilled. Thus, the emphasis on the quality of TVET teachers' education training of Faculty of Technical and Vocational Education (FTVE), Sultan Idris Education University (UPSI) has become an interesting issue that needs exploration. To evaluate the effectiveness of the education graduates, a quantitative survey research design using the Stuffelbeam evaluation model was carried out. The samples were FTVE graduates that have been placed in secondary schools and vocational colleges all over Malaysia. A total of 111 respondents have answered the questionnaire. The research findings showed that the level of professional knowledge, skills and practice were high. However, parallel to the concept of continuous improvement, the elements that are at the level of moderate will be evaluated for improvement. These research findings were expected to give some information to policy maker in TVET Teachers Training Provider to increase the quality of TVET graduates in UPSI specifically and Malaysia in general in order to uphold the aspiration to become a developed nation by 2020 .
\end{abstract}

Keywords: TVET; Technical and Vocational Education; TVET Teachers; UPSI

\section{Introduction}

Teacher education has been challenged by the need to enhance the new teachers' ability to implement new pedagogical approaches and take advantage of ICT for teaching and learning (Paivi Hakkinen et. al, 2017). The human capital development especially teachers in the field of technical and vocation education are a critical factor to generate and maintain economic growth specifically in the formation of skilled workers (Paryono, 2015). The availability of highly skilled work force is important in supporting the transformation of the entire economic sector towards activities that are intensified with knowledge, generate labour productivity and attract investments. Thus, the government of Malaysia has invested a large amount of money in the education sector. The investment in education field plays a major role in improving the social mobility and wellness of the citizens (RMK-11, 2015).

The $11^{\text {th }}$ Malaysia Plan, Rancangan Malaysia Kesebelas, (RMKe-11), 2016-2020, will continue carrying the agenda of producing human capital that are knowledgeable, skilled and possess positive attitude to develop in the global economy. The government will focus on four fields: improving the efficiency of labor market to increase economy growth, transform TVET to fulfil the industrial needs, strengthen the life-long learning to increase knowledge and improve the quality of education system to increase the student outcome and the excellence of institutions. The economy agenda highlighted in the RMKe-11 is expected to create 1.5 million jobs by 2020 by targeting improvement in labor productivity and reducing dependency on low-skilled foreign laborers, both due to the continuous transformation of labour-oriented economy towards knowledge and innovation-oriented economy. About $60 \%$ of the expected job opportunities require skills related to TVET (Razali, 2012).

TVET is recognized as the driver of transformation in order for Malaysia to generate skilled human capital. In general, this field will create world class human capital that is needed by Malaysia in the final phase of the country becoming a developed nation (RMK-11). Although various efforts have been taken by the Ministry of 
Education and related agencies to encourage and inform the public regarding the strength of existing technical and vocational education in Malaysia, most of the students and parents still choose academic stream rather than vocational stream (Abd Hair et al., 2011).

\subsection{Employability of TVET Teacher Graduates in Malaysia}

In Malaysia, the demand for employable higher education graduates has resulted in a national strategy that outlines desirable graduate attributes including "hard," discipline-specific skills and "soft," generic skills. The marketability skills and main skills, such as the popular competency skills are the impression of the concept widely known as generic skills (Bekri et al., 2011, Mohamad Sattar et al., 2012). It is also referred to as generic ability, although it is not a main skill (Berntson, Nääswall \& Sverke, 2011). The purpose of this skill is to find the basis to recognize a set that is important among the skills that support achievement in task-based activities which are the central to any job (Cassidy, 2006; Guile \& Young, 1998; Mohd Yusof et al., 2010).

Although generic skills have unique application for work place and job roles, it is also important to know that it is totally transferable (Kerajaan Australia, 2007; Ab Rahim \& Ivan, 2007; Fitrisehara, 2008). However, there are also studies that show that there is a discrepancy between learnt skills and the needs of the job (Fuller \& Unwin, 2003; Hesketh, 2000; Lave \& Wenger, 1991; Lesgold et al., 1997; Gazali, 2010; Noraini \& Noor, 2008; Nilsson, 2010). The learnt generic skills or the ones being used at the work place will also be used in other countries.

For example, the teamwork skill being applied in a fast-food restaurant can be transferred and applied by a waitress working in a hotel. In this globalization era, most of the employers need their employees that not only possess technical or hard skills but also generic skills or soft-skills. Employees that possess soft-skills will be able to adapt to any working situation and versatile (multi-skilled) suitable with the needs of the current job market (Overtoom 2000; Safarin \& Kamarudin 2004; Ab. Rahim \& Ivan, 2007). The focus on various skills of employees popularized the term employability.

Numerous terms were used to explain the meaning of employability. Most of the terms focus on the tittle related to the description of personality, character, behavior, communication, problem-solving, decision-making and management of organization (Yahaya Buntat, 2005; Ab Rahim \& Ivan, 2007; Fitrisehara, 2009). According to Lankard (1990), the employability skill is the description of skills such as personal, interpersonal and also good attitude and behavior. The existing skills will enable the employee to adapt with the changes in working environment. However, the continuous improvement of skilled teachers must often be evaluated to ensure the high quality of TVET graduates.

According to Shulman (1987), the knowledge required for teaching is divided into three types: content knowledge (knowledge of the matter being taught), pedagogical knowledge (knowledge of teaching methods) and also the knowledge with teaching content (knowledge of teaching methods appropriate to the subject taught). Experienced instructors are clearly supposed to master all three of these aspects to help develop good and quality coach. By viewing teachers as specialists in promoting learning, it is reasonable to see them as experts such as other areas that are able to share knowledge, experience and expertise with the simple result of their experience.

\subsection{Stuffelbeam Evaluation Model}

This model had been introduced by Stufflebeam (1966). The CIPP model was developed during the late 60s to fulfill the need for an objective evaluation. The CIPP model was used in the Austin Texas laboratory and it then was fully used in Dallas. CIPP was designed to evaluate the project funded by the Elementary and Secondary Education Act 1965 (ESEA). Billions were used to upgrade the school system and to improve the learning environment among special students. All these districts needed to be evaluated in order to fulfill the aspiration of the population but most of the teachers were unable to do so. Therefore, a resolution was achieved to train the teachers through the collaboration with the Ohio State University. This was how the CIPP Model was created.

The Stufflebeam evaluation model was designed to collect useful data to assist decision making. There were two suggested results, which were:

\section{i. Implementation ( the result of process ) \\ ii. Repetition (to make decision).}

The process evaluation served as the guide to implement a decision. The result of the evaluation served as the guide to decision. In the context evaluation, it acts to assist towards decision making at the level of planning and the input evaluation is more towards making restructuring decision. In order to explain the relationship between the dimensions, the following figure shows the CIPP Model by Stufflebeam (1985) that has been adapted and simplified by Razali Arof (1991). The related dimensions are context evaluation (Context), input, process and 
product.

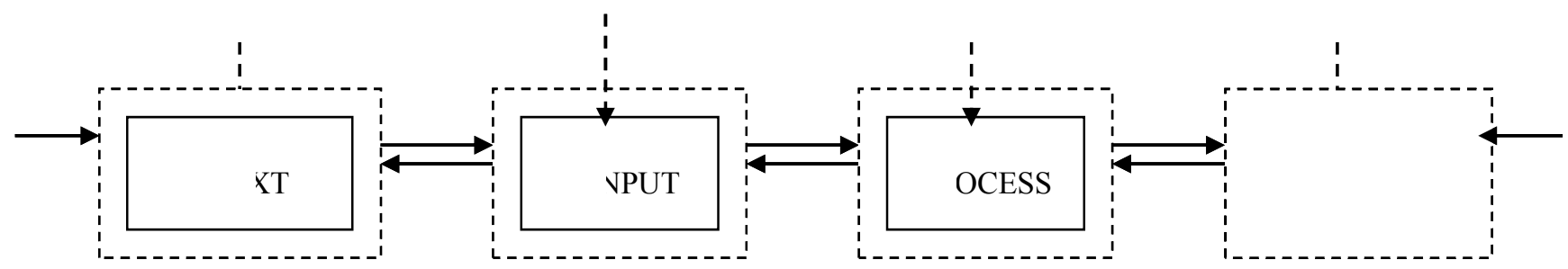

Figure 1. CIPP Education Evaluation Model (adapted and simplified).

\section{Conceptual Framework of Research}

The conceptual framework of this research was adapted from the CIPP Education Evaluation Model that emphasizes the relationship between four factors which are context, input, process and product. In this research, the context was observed from the aspect of education result that had been determined by the Ministry of Higher Education (MOHE), Education University of Sultan Idris (UPSI) and Faculty of Technical and Vocational Education (FTVE). The inputs were the result of the Malaysia Teacher Standards (MTS) that includes professional practice, pedagogy skills, knowledge and skills. The objectives of offered programs and the result of learning were also included.

For the conveying process, the evaluations were done based on the teaching and learning, implemented curriculum and evaluation method. The final product, which are the graduates, were observed from two main aspects which were knowledge and skills of various aspects called graduate employability Figure 2 summarizes the aspects of context, input, process and output of this research. In development of our program, we adapted Malaysian Qualification Agency standard that every program must have their own Program Education Objective (PEO), Program Learning Outcomes (PLO) and also Course Learning Outcomes (CLO). Every teaching and learning $(\mathrm{TnL})$ process must complete from planning until the end of the teaching session with evaluation or assessment. Figure 2 shows our framework in this research.

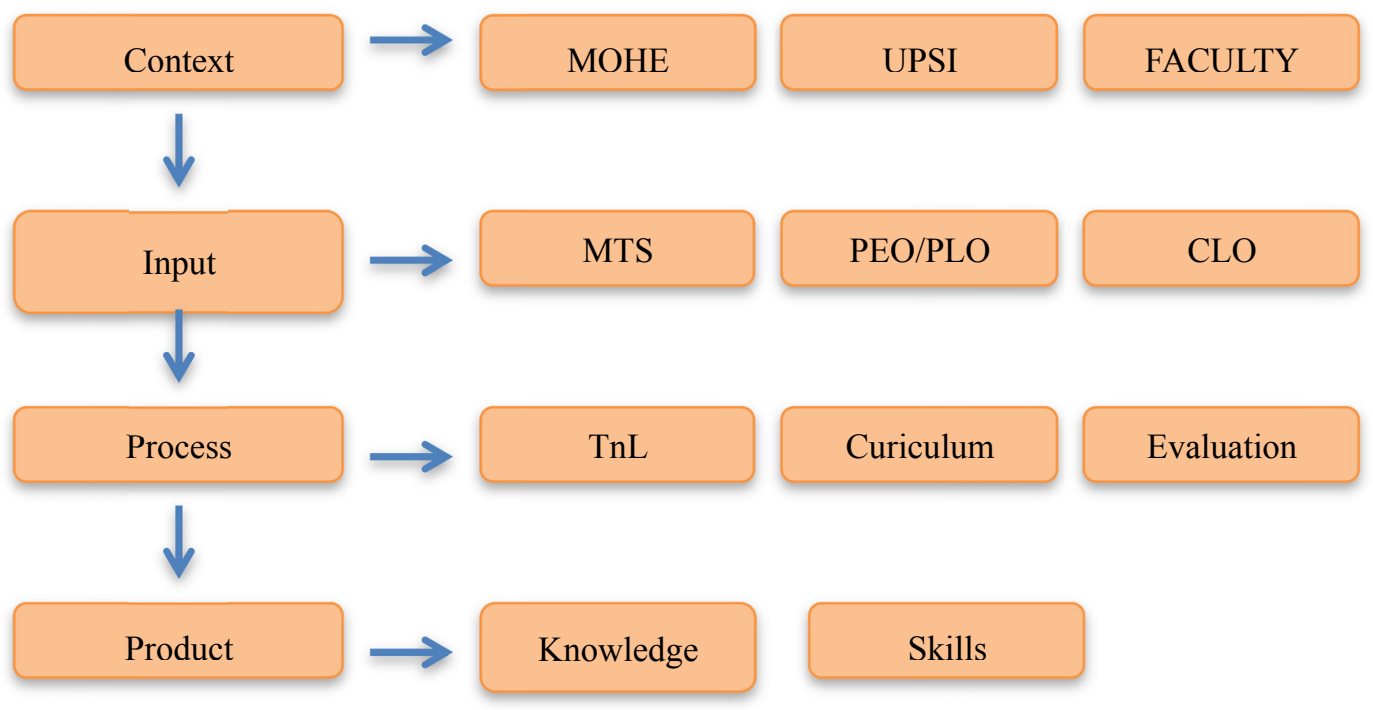

Figure 2. Conceptual Framework of Research

\subsection{Research Problem}

Various efforts been taken in making Malaysia a developed high-income nation by the year of 2020, such increasing the marketability of graduates (Kerajaan Malaysia, 2009). The UPSI is also putting its efforts to add value to the graduates through various programs.

However, there is no research been done to evaluate the effectiveness of FTVE graduates on the marketability and ability of graduates of Bachelor of Life Skills with Hons., Bachelor of Household Economy with Hons., and Bachelor of Agricultural Science with Hons. Thus, there is a need to study the strengths and weaknesses of implemented training programs on the readiness of the graduates to teach in schools. With this, the faculty will 
be better able to restructure the programs with added value to boost the marketability of the graduates.

\subsection{Research Objectives}

1. Identify the implementation level of curriculum, teaching and learning and the best evaluation to produce high quality FTVE graduates.

2. Study the effectiveness level of implementation of programs offered by FTVE in order to produce innovative and competent graduates.

\subsection{Research Questions}

1. What is the implementation level of curriculum, teaching and learning and the best evaluation to produce high quality FTVE graduates?

2. What is the effectiveness level of implementation of programs offered by FTVE in order to produce innovative and competent graduates?

\section{Research Methodology}

This research is a quantitative survey research where the perceptions of the FTVE graduates were measured. This quantitative research used a questionnaire as the research instrument to evaluate the perceptions of the FTVE graduates on the effectiveness of implementation of curriculum in producing teachers who are knowledgeable and skilled. The determined variables are shown in the Figure 3.

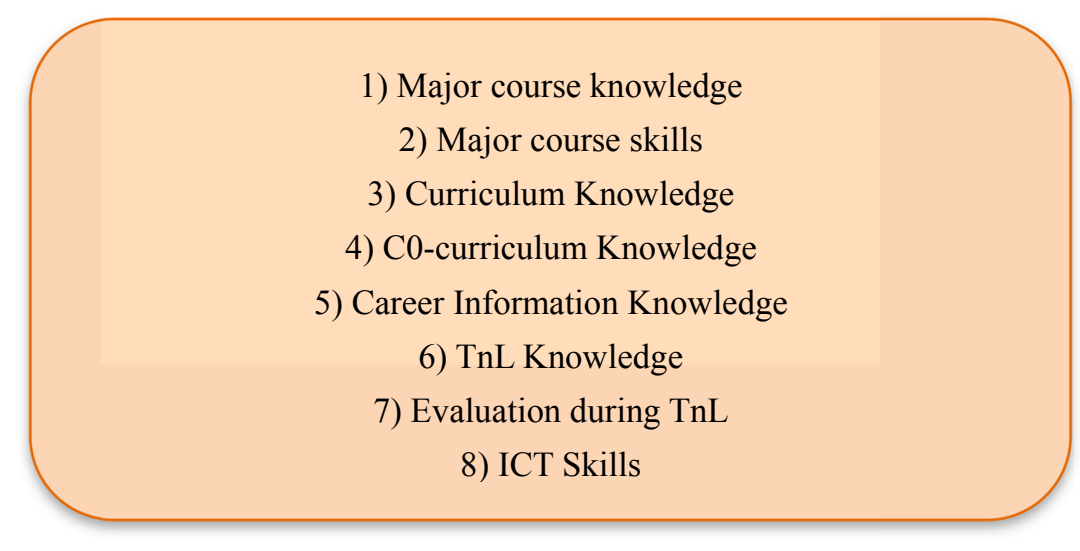

Figure 3. Main Research Constructs

The determined variables were the guides in developing the questionnaire. Chuan Yian Paw (2006) stated that a questionnaire has many functions such as recording the observation of the respondents' behavior. Mohd Majid (2005) on the other hand suggested that this method is useful in gathering information about a situation. He added that questionnaires can be used to obtain information regarding facts, beliefs, feelings, desires and etc.

\subsection{Sampling}

The data from the academic department of UPSI regarding the number of FTVE graduates are shown in the table 1 below. Based on Krejcie and Morgan (1970), the minimum number of samples needed was only 86 samples.

Table 1. Number of FTVE Graduates

\begin{tabular}{cccc}
\hline No. & Year & Program & Total \\
\hline \multirow{2}{*}{1} & \multirow{2}{*}{2013} & Life Skills & 145 \\
& & Agricultural Science & $\mathbf{1 1 4}$ \\
& & Household Economy & 99 \\
\hline
\end{tabular}

* Only the 2013 graduates were sampled for this research.

\subsection{Instrumentation}

The research was carried out using a questionnaire that consisted of 6 sections. The questionnaire was developed based on the research done by the Faculty of Social Sciences and Humanity, UPSI. However, it was modified to make it more appropriate for the graduates of FTVE. According to Chua Yian Paw (2006), a questionnaire instrument must have the following criteria: 
- suitable with the readiness of the respondents

- systematic format

- clear instructions

- letters and documents enclosed with the questionnaire

- a pilot study must be done before using the instrument for real research

In this research, the researcher classified the scales specifically as shown in the Table 2 . Table 2 shows that there are four scales being used to measure the perception of the graduates. The score of 1.00 to 2.33 are interpreted as low perception, the score of 2.34 to 3.66 are interpreted as moderate perception, and the score of 3.67 to 5.00 are interpreted as having high and strong perception.

Table 2. Scale to measure the level of effectiveness

\begin{tabular}{cc}
\hline Level Interpretation & Score \\
\hline Low & $1.00-2.33$ \\
Moderate & $2.34-3.66$ \\
High & $3.67-5.00$ \\
\hline
\end{tabular}

\section{Research Findings}

These are the findings obtained from the research carried out among the graduates of UPSI. The respondents were the graduates of Bachelor of Agricultural Science with Hons (BASH). The findings are discussed based on the research questions.

Demography of respondents

\begin{tabular}{cc}
\hline Graduates & Total \\
\hline Male & 40 \\
Female & 71 \\
\hline
\end{tabular}

\subsection{Research Question 1}

What is the implementation level of curriculum, teaching and learning and the best evaluation to produce high quality FTVE graduates?

Table 3 shows the min score and standard deviation of BASH effectiveness of curriculum, teaching and learning and the best evaluation. The highest min was for the $\mathrm{TnL}$ knowledge criteria (mean=4.36, s.d=.30). The lowest score was for career knowledge criteria with a score of (mean $=3.25$, s.d $=0.73$ ).

Table 3. Min Score and Standard Deviation for Curriculum Implementation of Agricultural Science Graduates

\begin{tabular}{ccc}
\hline Criteria & Min & Standard Deviation \\
\hline Knowledge & 3.764 & 0.647 \\
Skills & 3.430 & 0.515 \\
Curriculum Knowledge & 3.861 & 0.596 \\
Co-curriculums Knowledge & 3.785 & 0.684 \\
Career Knowledge & 3.250 & 0.730 \\
TnL Knowledge & 4.363 & 0.453 \\
Evaluation Knowledge & 4.193 & 0.466 \\
ICT Skills & 3.906 & 0.806 \\
Language Skills & 3.583 & 0.742 \\
Generic Skills & 4.000 & 0.744 \\
Application of Curriculum Knowledge & 3.785 & 1.121 \\
Application of Co-Curriculums Knowledge & 3.924 & 0.964 \\
Application of ICT Knowledge & 3.742 & 0.879 \\
Application of Language Knowledge & 3.667 & 0.605 \\
Application of Generic Knowledge & 4.017 & 0.897 \\
Application of Moral Values Knowledge & 4.353 & 0.513 \\
\hline
\end{tabular}

Note: $\mathrm{N}=111$; Overall mean $=3.852 ;$ s.d $=0.591$ 


\subsection{Research Question 2}

What is the effectiveness level of implementation of programs offered by FTVE in order to produce innovative and competent graduates?

Table 4 shows the min score and standard deviation of BASH implementation of programs. The highest min was for item 'helps me in increasing interpersonal communication skill' (mean=4.16, s.d=.95). The lowest score was for item 'helps me in increasing analytical skill' (mean=3.97, s.d=0.46).

Table 4. Mean Score and Standard Deviation for Effectiveness of Agricultural Science Program Implementation

\begin{tabular}{lcc}
\hline \multicolumn{1}{c}{ Criteria } & Min & Standard Deviation \\
\hline Interpersonal communication & 4.156 & 0.954 \\
Helps me in increasing the skill of critic and critical thinking & 3.969 & 0.861 \\
Helps me in increasing problem-solving skill & 3.938 & 0.948 \\
Helps me in increasing analytical skill & 3.875 & 0.907 \\
Helps me in working as a team & 4.000 & 0.984 \\
Helps me in applying positive values and Experiences & 4.063 & 0.914 \\
Helps me in increasing exploration of general knowledge and current issues & 4.125 & 0.942 \\
Help me in increasing High Order Thinking Skill (HOTS) & 4.063 & 0.948 \\
Helps me in increasing skills in the field of entrepreneurship & 3.969 & 0.990 \\
\hline
\end{tabular}

Note: $\mathrm{N}=111$; Overall Mean $=4.017$; $\mathrm{s} . \mathrm{d}=0.897$

\section{Discussion}

The research findings showed that the effectiveness level of the program and curriculum implementation in FTVE, UPSI is high. This is corresponding with globalization era and the developing world. In this globalization era, most of the employers need their employees that not only possess technical or hard skills but also generic skills or soft-skills. Employees that possess soft-skills will be able to adapt to any working situation and versatile (multi-skilled) suitable with the needs of the current job market (Overtoom, 2000; Safarin \& Kamarudin, 2004; Ab. Rahim \& Ivan, 2007).

Knowledgeable and skilled graduates will develop the human capital in order to assist Malaysia in the succession of the $11^{\text {th }}$ Malaysia Plan, Rancangan Malaysia Kesebelas, (RMKe-11). This statement supported by findings in this research shows that our level of knowledge amongst out graduate very high. Thus, the government will focus on four fields which are improving the efficiency of labor market to increase economy growth, transform TVET to fulfil the industrial needs, strengthen the life-long learning to increase knowledge and improve the quality of education system to increase the student outcome and the excellence of institutions.

This research used the CIPP Education Evaluation Model and emphasized the relationship between four main factors which are contexts, input, process and input from the perspective of learning output as determined by the MOHE, UPSI and FTVE. All the inputs were from the Malaysian Teacher Standards (MTS) that includes professional practice, pedagogy skills, knowledge and skills. The objectives of offered programs and the result of learning were also included. Therefore, FTVE, UPSI is on the right track of developing graduates who are knowledgeable and skilled.

\section{Conclusion}

This research is expected to provide an understanding regarding the implementation of curriculum and can be used to develop and action plan that assists in increasing the effectiveness of technical and vocational training implementation. This will also assist towards achieving the nation's aspiration of becoming a high-income nation by 2020. Comprehension of the processes that exist within the system of developing skilled workers will enable the nation in planning the human capital to lead the economy parallel with the Economy Transformation Plan (ETP) that will be implemented by the government in order to achieve the vision 2020.

\section{Acknowledgements}

This research funded by Research Management and Innovation Centre, Sultan Idris Education University under University Research Grant (GPU) Top Down for Faculty of Technical and Vocational Education.

\section{References}

Abd Hair Awang, Rahim Md. Sail, Khadijah Alavi \& Ismi Arif Ismail. (2011). Image and Students' Loyalty 
Towards Technical And Vocational Education And Training. Journal of Technical Education and Training, 3(1), 13-28.

Abu Bakar Nordin. (1991). Kurikulum Perspektif Dan Pelaksanaan. Kuala Lumpur: Pustaka Antara.

Azizi Yahya (1992). Aspirasi Pekerjaan Dan Masalah Akademik Di Kalangan Pelajar Sekolah Menengah Vokasional Pertanian Rembau, Negeri Sembilan. Tesis Sarjana yang tidak diterbitkan. UKM.

Bekri R. et al. (2011). Penguasaan Core Abilities Pekerjaan Dalam Kalangan Graduan Diploma Kemahiran Malaysia Penyejukan Dan Penyaman Udara: Satu Kajian Kes. Prosiding Seminar Serantau Kelima Tahun 2011 Universitas Riau, Pekan baru dan Universiti Kebangsaan Malaysia pada 12 - 14 Mei 2011, Pekan Bau Riau, Indonesia.

Benson, J., \& Micheal, W. B. (1990). A Twenty-Year Perspective On Evaluation Study Design. In H. J. Walberg \& G. D. Haertel (Eds.), The International Encyclopedia of Educational Evaluation (pp. 545-553). Oxford, England: Pergamon.

Berntson, E., Nääswall, K., \& Sverke, M. (2011). Investigating the relationship between employability and selfefficacy: A cross-lagged analysis. European Journal of Work and Organizational Psychology, 17(4), 413-425. https://doi.org/10.1080/13594320801969699

Cassidy, S. (2006). Developing employability skills: peer assessment in higher education. Education + Training, 48(7), 508-517. https://doi.org/10.1108/00400910610705890

Cronbach, L. J. (1963). Designing Evaluation of Educational of Social Programs. San Francisco: Jossey-Bass.

Finch, C. G. (1984). Strategic Planning In Education: A Guide For Policy Makers. Alexandria, Va: National School Boards Association.

Fitrisehara, K., Hamzah, R., \& Bakar, A. R. (2009). Employability Skills among the Students of Technical and Vocational Training Centers in Malaysia. European Journal of Social Sciences, 9(1), 147-160.

Fitz-Gibbon, C. T., \& Morris, L. L. (1978a). Evaluator's Handbook. Beverly Hills: Sage.

Fitz-Gibbon, C. T., \& Morris, L. L. (1978b). How To Design A Program Evaluation . Beverly Hills: Sage.

Fuller, A., \& Unwin, L. (2003). Learning as Apprentices in the Contemporary UK Work-place: creating and managing expansive and restrictive participation. Journal of Education and Work, 16(4), 407-426. doi:10.1080/1363908032000093012.

Gainer (1988). ASTD Update: Basic Skills.

Ghaziah Ghazali \& Dawn Bennet (2017). Employability for music graduates: Malaysian educational reform and the focus on generic skills. International Journal of Music Education. https://doi.org/10.1177/0255761416689844

Guile, D., \& Young, M. (1998). Apprenticeship as a conceptual basis for a social theory of learning. Journal of Vocational Education \& Training, 50(2), 37-41. https://doi.org/10.1080/13636829800200044

Gurvinder Kaur Gurcharan Singh \& Sharan Kaur Garib Singh. (2008). Malaysian Graduates' Employability Skills. UNITAR E-JOURNAL, 4(1), January 2008.

Harris, B. W. (1980). Improving Staff Performance Through In Service Education. Boston. Allyn and Bacon.

Harvey, L. (2001). Defining and Measuring Employability. Quality in Higher Education, 7(2), 97-109. https://doi.org/10.1080/13538320120059990

Hassan, R., Razzaly, W., \& Alias, M. (2012). Technical and Vocational Education Teachers in Malaysia. A country paper presented during the Experts Meeting organised by SEAMEO VOCTECH and UNESCO-UNEVOC in Conjunction with International Conference on The Excellence in Teacher Education and Research Innovation by Rajabhat Universities Network, Bangkok, Thailand, 25-28 December 2012.

Hesketh, A. (2000). Recruiting an elite? Employers' perceptions of graduate employment and training. Journal of Education and Work, 13(3), 245-71. https://doi.org/10.1080/713676992

Kay, C., Fonda, N., \& Hayes, C. (1998). Growing an innovative workforce: a new approach to education and training. Education + Training, 34(3), 267-275. https://doi.org/10.1108/00400919810234054

Kementerian Pendidikan Malaysia. (1987). Cadangan Strategi Pendedahan Dan Latihan Untuk Pelaksanaan Kurikulum Bersepadu Sekolah Menengah. Kuala Lumpur: Pusat Perkembangan Kurikulum.

KilPatrick, S., \& A1len, K. (2001). Review of research: factors influencing demand for voca-tional education 
and training courses. Kensington: National center vocational education research.

Lave, J., \& Wenger, E. (1991). Situated Learning - Legitimate Peripheral Participation. Cam-bridge: Cambridge University Press. https://doi.org/10.1017/CBO9780511815355

Lesgold, A., Feuer, M. J., \& Black, A. M. (1997). Transitions in Work and Learning: Implica-tions for Assessment. Washington: National Academy Press.

Loh Poh Seng (1996). Kesesuaian Kurikulum Program Bacelor Pendidikan (Sains Pertanian), Universiti Pertanian Malaysia. Latihan Ilmiah tidak diterbitkan.

Mardevan a/l Marimuthu (1991). Kajian Keberkesanan Kursus Dalam Perkhidmatan Untuk Guru-Guru Mata Pelajaran Kemahiran Hidup. Tesis sarjana, Universiti Kebangsaan Malaysia, Bangi.

Ministry of Human Resources. (2011). Kajian Tahap kebolehkerjaan graduan persijilan kemahiran Malaysia di Institut Latihan Kemahiran Awam.

Mohd Nasir Ali (1994). Pengaliran Pelajar Di Sekolah Menengah Rendah Dan Kesannya Terhadap Status Mata Pelajaran Elektif. Jurnal Pendidikan.

Mohd Yusof Husain, Seri Bunian Mokhtar, Abdul Aziz Ahmad, \& Ramlee Mustapha (2010). Importance of Employability Skills from Employers' Perspective. Procedia - Social and Behavioral Sciences, 7(C), 430-438. https://doi.org/10.1016/j.sbspro.2010.10.059

Mohd. Gazali Abas. (2011). Isu-isu semasa Dalam Pendidikan Latihan Teknikal dan Vokasional di Malaysia. $J P M$. Unit Perancang Ekonomi. Kuala Lumpur.

Nilsson, S. (2010). Enhancing individual employability: the perspective of engineering graduates. Education + Training, 52(6/7), 540-551. https://doi.org/10.1108/00400911011068487

Noraini Mohd Noor \& Noor Murni Abd Sukor (2008). Penerapan Kemahiran Employability di Institut Latihan Perindustrian Pasir Gudang Johor.

Nurita, Shaharudin, \& Ainon. (2004). A survey of students' employability skills: A case of Unitar.

Omar, M. K., Bakar, A. R., \& Rashid, A. M. (2012). Employability skill acquisition among Malaysian community college students. J. Soc. Sci., 8, 472-478. https://doi.org/10.3844/jssp.2012.472.478

Overtoom, C. (2000). Employability skills: An update. ERIC Digest No. 220.

Päivi Häkkinen, Sanna Järvelä, Kati Mäkitalo-Siegl, Arto Ahonen, Piia Näykki \& Teemu Valtonen. (2017). Preparing teacher-students for twenty-first-century learning practices (PREP 21): a framework for enhancing collaborative problem-solving and strategic learning skills. Teachers and Teaching, 23(1), 25-41, https://doi.org/10.1080/13540602.2016.1203772

Paryono, P. (2015). Approaches to preparing TVET teachers and instructors in ASEAN member countries. TVET@Asia, 5, 1-27.

Quek Ai-Hwa (2005). Learning for the workplace: a case study in graduate employees' generic competencies. Journal of Workplace Learning, 17(4), 231-242. https://doi.org/10.1108/13665620510597185

Rahim, M. B., Hashim, M. N., \& Baser, J. A. (2011). Tinjauan ke atas keterampilan.

Rajiv Rasikchandra Malkan. (2009). Post-Secondary Technical Vocational Education Training: A Qualitative Case Study of Industrial Training Institute (ITI) In Maharasthra State, India. PhD Dissertation of the Graduate College at the University of Nebraska.

Ramlah Hamzah (1992). Persepsi Dan Masalah Guru Terhadap Mata Pelajaran Kemahiran Hidup. Jurnal Pendidikan Guru. Bil. 9 - 1993 (ISSN: 01277316): 50 -71.

Rancangan Malaysia ke-11 (RMK-11). (2015). Kerajaan Malaysia. Report.

Rasul, M. S. et al. (2009). Aspek Kemahiran "Employability" yang Dikehendaki Majikan Industri Pembuatan Masa Kini (Aspects of Employability Skills Needed by the Manufacturing Industries Employers). Jurnal Pendidikan Malaysia, 34(2), 67-79.

Razali Arof (1991). Pengantar Kurikulum. Kuala Lumpur: Dewan Bahasa Dan Pustaka.

Shakir, R. (2009). Soft skills at the Malaysian institutes of higher learning. Asia Pacific Educ. Rev, 10, 309-315. https://doi.org/10.1007/s12564-009-9038-8

Sharifah Mohd Nor. (1989). Perlaksanaan Masa Lanjutan ( Kemahiran Hidup ) Di Sekolah Menengah: Satu 
kajian Perintis.

Shulman, L. (1987). Knowledge and teaching: foundations of the new reform. Harvard Educational Review, 57(1), 1-22. https://doi.org/10.17763/haer.57.1.j463w79r56455411

Stufflebeam, D. L., Folely. W. J., Gephart, W. J., Guba, E. G., Hammond R. L., Merrimman, H. O., \& Provus, M. M. (1971). Educational Evaluation And Decision-Making. Itasca, IL: F.E. Peacock.

The Conference Board of Canada. (1996). Employability Skills. Ottawa Ontario.

Universiti Putra Malaysia (UPM). (2012). Kajian Tahap Penerimaan Masyarakat Terhadap Latihan Kemahiran. Report.

\section{Copyrights}

Copyright for this article is retained by the author(s), with first publication rights granted to the journal.

This is an open-access article distributed under the terms and conditions of the Creative Commons Attribution license (http://creativecommons.org/licenses/by/4.0/). 